DOI: https://doi.org/10.32839/2304-5809/2021-3-91-19

УДК 371.398

Моторіна Д.А., Сиротенко В.П.

Державний вищий навчальний заклад

«Донбаський державний педагогічний університет»

\title{
ФОРМУВАННЯ НАВИЧОК ВИРАЗНОГО ЧИТАННЯ В УМОВАХ ДИСТАНЦІЙНОГО НАВЧАННЯ
}

\begin{abstract}
Анотація. У статті розглянуто питання формування виразного читання в умовах дистанційного навчання. Проаналізовано, як прищеплювати дітям навички виразного читання, коли безпосередній контакт учитель - учень ускладнений епідеміологічним випадком. Висвітлено аспекти навчання виразного читання на прикладі вірша Наталії Забілої «Кіт і півник» під час загострення епідеміологічної ситуації в країні в умовах упровадження онлайн навчання. Особливу увагу приділено якісному і грунтовному перебігу навчально-виховного процесу під час e-learning з дітьми, які не мають вільного доступу до інтернету, спеціального обладнання чи зіткнулися з іншими перешкодами на шляху учіння. Окреслено ряд аспектів, які потребують подальшого вивчення: наскільки жанрово-родова природа твору позначається на засобах виразності його читання; які методичні підходи найдоцільніше застосовувати при використанні різних дистанційних платформ навчання.
\end{abstract}

Ключові слова: виразне читання, дистанційне навчання, епідеміологіча ситуація, молодші школярі, технічне забезпечення.

Motorina Darina, Syrotenko Valerii State Higher Educational Institution «Donbas State Pedagogical University»

\section{DEVELOPMENT OF EXPRESSIVE READING SKILLS IN THE CONDITIONS OF DISTANCE LEARNING}

Summary. The article looks into the development of expressive reading in conditions of distance learning. It is analyzed how to foster children's skills of expressive reading, when direct interaction between a teacher and a student is complicated by epidemiological case. Aspects of learning expressive reading is highlighted on the example of Natalia Zabila's poem "Cat and Rooster" during the exacerbation of the epidemiological situation in the country. Particular attention is paid to the qualitative and thorough course of the educational process during e-learning with children who do not have free access to the Internet, special equipment or other obstacles to learning. It was found that in Ukraine the national strategy for the development of primary education is under development, and therefore there are acute problems that complicate the provision of educational process in such a way that students with different conditions of technical and material support are competitive compared to primary students of leading eastern and western schools. Recommendations for the development of reading culture are given and they include many aspects. Emphasis is made on the development of reading skills associated with writing exercises: listening and visual dictation, writing, calligraphy. Particular attention is paid to work with parents, everything should be aimed at overcoming the psychological barrier between a child a teacher, creating space for communication, restoring balance and effective feedback: constructive, constant, consistent, rational, and formative. It is noted that an important point in achieving a clear reading of this work is the composition of scores of individual fragments. It was found out that the work on expressive reading motivates children for self-improvement in the field of expressive reading, for search for adequate reading aids that best meet both the content and artistic features of the text and its personal perception. A number of aspects that need further study are outlined: to what extent the genre-generic nature of the work affects the means of its reading expression; what methodological approaches are most appropriate to take when using different distance learning platforms. Keywords: expressive reading, distance learning, epidemiological situation, primary schoolchildren, technical support.

$\Pi^{2}$ остановка проблеми. За останній рік стратегічна мета освіти в кожній, без винятку, країні зазнала докорінних змін в умовах економічної, соціальної та епідеміологічної ситуації, що спровокувало появу, розробку та удосконалення нових методів та інструментів упровадження дистанційної освіти. В Україні національна стратегія розвитку освіти початкової ланки знаходиться на етапі розбудови, і тому існують гострі проблеми, які ускладнюють забезпечення владою навчально-виховного процесу таким чином, щоб у результаті дистанційного навчання здобувачі освіти 3 різними умовами технічного та матеріального забезпечення були конкурентно спроможними порівняно з школярами другого циклу провідних східних та західних шкіл. Шляхом про- ведення дослідження, а саме опитування освітян та ознайомленням зі стратегією розвитку освіти в Україні ми обрали, на наш погляд, найбільш суттеву проблему, що стосуеться обмеженості доступу до якісної освіти окремих категорій населення (це діти, які проживають у сільській місцевості, діти з особливими освітніми потребами, обдарована учнівська молодь, діти мігрантів) під час карантинних заходів [1].

У даній статті ми висвітлюемо питання навчання виразного читання на прикладі вірша Наталії Забілої «Кіт і півник» під час загострення епідеміологічної ситуації в країні в умовах упровадження форми дистанційного навчання.

Аналіз останніх досліджень і публікацій. У контексті нашої роботи хочемо виокремити пра- 
цю Ю. Линника [2], який подав обѓрунтування динаміки популярності дослідження проблеми упровадження дистанційного навчання в Україні та дослідження інших науковців, які приділили увагу фракторам розвитку та напрямам удосконалення дистанщійної форми навчання, а саме О. Романовського [3], О. Квасника [4], Г. Підлужної [5], що звернула увагу на лінгвометодичні аспекти формування виразності читання молодших школярів. На їі думку, «виразне читання художніх творів, у яких розкривається краса навколишнього світу, внутрішній світ людини, їі переживання, думки, мрії, розширюе життевий досвід молодших школярів, сприяе усвідомленню ними загальнолюдських цінностей, норм поведінки, які підтримуються суспільством» [5].

Виділення не вирішених раніше частин загальної проблеми. Формування читацької культури включає багато аспектів, зокрема й вироблення навичок виразного читання. Адже осягнення естетичної природи художнього тексту потребуе виразного читання, яке, 3 одного боку, стимулюе глибоке проникнення вчителя (учня) у змістово-художні особливості тексту, а з іншого - відкриває перед дитиною можливості виявити своє «Я», оскільки варіант відтворення художнього твору завжди сугубо індивідуальний. В умовах неповного або відсутнього необхідного технічного забезпечення учнів фахівцями апробовані такі методи роботи, які грунтуються на комунікуванні за допомогою теледонного зв'язку.

Формування навичок виразного читання потребує копіткої, цілеспрямованої, щоденної роботи. Це завжди було не просто, а за умов карантинно-дистанційної організації всього навчального процесу набувае нових аспектів. Тобто, частина загальної проблеми полягає у тому, що вчитель повинен забезпечити повноцінне виконання й засвоєння типової навчальної програми 1-4 класів, шукаючи при цьому нових методичних підходів, прийомів і форм роботи.

Мета статті. Головною метою цієї роботи є обІрунтування прищеплення дітям навички виразного читання, коли безпосередній контакт учитель - учень ускладнений через епідеміологічну ситуацію.

Виклад основного матеріалу. Читання складний та багатогранний процес, навичка якого формуеться упродовж не одного року, тому навчити по-справжньому добре читати не легко. Говорячи ж про багатогранність, наголосимо, що одним із їі чинників є виразність читання, коли насамперед слід передати ідею твору і своє ставлення до того, про що учень читає. Не слід забувати, що розвиток навички читання передусім пов'язаний із письмовими вправами: слуховими та зоровими диктантами, списуванням, каліграфрiєю. В деяких країнах до відбору на вакантні посади існуе вимога: навик читання має переважати 400 слів за хвилину із повним розумінням тексту [6]. Постають питання: як в умовах дистанційної форми навчання виховати конкурентно спроможне покоління; забезпечити умови для інтелектуального, соціального, морального розвитку учнів; прищепити любов до книги, зацікавити літературною спадщиною нашого народу; сформувати у школярів навичку виразного читання. Наголошуємо, що цей важливий показ- ник літературної освіти школярів діалектично складається 3 двох компонентів - техніки читання та тих виражальних прийомів, які дозволяють адекватно передати авторсько-особистісне розуміння ідейної наснаженості твору.

"Смислові» показники виразності дотикаються до уміння використовувати логічні наголоси та паузи, удаватися до інтонаційних переломів, підвищення і зниження тону, варіювання темпу мовлення (це все при необхідності позначається знаками партитури [7]), тобто, всього того, що демонструє рівень ідейно-художнього осмислення тексту.

У нашому дослідженні ми свідомо уникаємо розмови про «технічні» показники виразності читання (правильна й чітка дикція, відповідно поставлене дихання у процесі читання, висота, сила, чистота голосу, дотримання орфоепічних правил вимови), для вироблення якої існують різноманітні вправи [5], акцентуючи увагу на іншому.

Запровадження карантину на весні 2020 року актуалізувало проблему дистанційного навчання, при розв'язанні якої більшість учителів виявили свої творчі та креативні здібності: радіоуроки, телеуроки, блоги, сайти, прямі ефіри, робота в системах керування навчанням Moodle, Google Classroom, aTutor, Learn.com, eCollege, ILIAS та всіма опробуваний і протестований Viber. Ïxній вибір у значній мірі обумовлювався технічно-інформаційними можливостями, але завжди слід пам'ятати про недопустимість жорстких дедлайнів при застосуванні різних форм дистанційного навчання.

Для забезпечення якісного i грунтовного навчально-виховного процесу під час e-learning 3 дітьми, які не мають вільного доступу до інтернету, спеціального обладнання чи зіткнулися 3 іншими перешкодами на шляху учіння, викладачі мають спланувати роботу так, щоб не допустити розриву в кількості отримуваних знань, якості надбаних умінь та навичок порівняно 3 однокласниками 3 ширшими інфрормаційнотехнічними можливостями.

Перш за все тьютор має знайти контакт із батьками дитини, адже вони - посередники навчального та керівники виховного процесу на час дистанщійного навчання. Робота з батьками має бути спрямована на подолання психологічного бар'єру між дитиною та вчителем, створення простору для спілкування, відновлення балансу та ефективного зворотнього зв'язку: конструктивного, постійного, послідовного, раціонального та формувального. Ефективність цих умов ми і спробуємо безпосередньо продемонструвати, працюючи над формуванням навичок виразного читання.

Віршована казка Наталі Забіли «Кіт і Півник» нами обрана невипадково. Твір легкий для сприймання й відтворення третьокласниками, тому після показового виразного читання (аудіозапис тексту у виконанні вчителя або актора варто продублювати на різних електронно-комунікативних системах, гарантувавши цим доступ кожного учня до прослуховування казки) вчитель у такий же спосіб надсилає один із пунктів домашнього завдання: створити добірку найбільш милозвучних одиниць мови у вірші і знайти приклади на противагу; потренуватися у вимовлянні одних та інших. 
За умови дистанційного навчання особливої ваги набувае проєктно-дослідницька індивідуальна робота, зміст якої заздалегідь повідомляеться учням. У нашому випадку це будуть: 1 - письмові відповіді на питання: «Який образ є головним у творі? Наскільки він допомагає сформулювати тему поезії?, «Як поетеса ставиться до головного героя? Чим це обумовлено? Яка загальна настроєвість вірша? Чи поділяете ви подібні авторські почування? Яке ідейне спрямування твору? До чого нас закликае письменниця?»; 2 - створення чек-листівок та топдобірок. Виконання завдань першої групи допоможе учням усвідомити, в яких випадках слід удатися до логічних наголосів та пауз, в якому темпі, з якою силою голосу варто читати текст, щоб передати його настрій. $\mathrm{У}$ другому разі третьокласники підводять до усвідомлення, що потрібно зробити підготовчу роботу, розминку це приверне увагу до виразного читання

Важливим моментом щодо досягнення виразного читання даного твору буде укладання партитур окремих фрагментів. Для прикладу учитель виготовляе й розсилає учням свої варіанти партитури третьої і четвертої строфи [8], а школярам пропонуеться завдання розробити партитуру читання реплік, які належать Півникові, Котикові, Лисичці та авторці, щоб засобами виразного читання якомога точніше передати риси характеру кожного з персонажів, донести до читача авторську позицію. Вагомість подібного завдання в тому, що змістові компоненти твору (виявлення рис характеру дійових осіб) реалізуються через засоби виразного читання, чим підкреслюеться значимість останнього.

Логічним завершенням усього комплексу задання щодо виразного читання казки Н. Забіли буде проведення Zоотконференщії. Це, поперше, створить ефект безпосереднього спілкування учитель - учні, учні - учні, по-друге, внесе елемент змагальності, адже діти пропонуватимуть власні варіанти виразного читання певних уривків, а учитель та інші однокласники виступатимуть у ролі журі. Така робота стимулюватиме дітей до самовдосконалення на ниві виразного читання, до пошуків адекватних читацьких засобів, які б найбільше відповідали як змістовохудожнім особливостям самого тексту, так і особистісному його сприйняттю.

Висновки i пропозиціï. Порушена нами проблема засвідчила, наскільки робота над формуванням навичок виразного читання важлива у плані здійснення загального змістово-художнього аналізу будь-якого тексту. А ще більша ії значимість полягае в тому, що, працюючи над виразним читанням, учень розкривається перш за все як особистість. Водночас проведене дослідження окреслило та запропонувало для розгляду цілий ряд аспектів, які потребують подальшого вивчення: наскільки жанрово-родова природа твору позначається на засобах виразності його читання; які методичні підходи найдоцільніше застосовувати при використанні різних дистанційних платформ навчання.

\section{Список літератури:}

1. Льовочкін С. Про Національну стратегію розвитку освіти в Україні на період до 2021 року. URL: http://ru.osvita.ua/legislation/other/36322/ (дата звернення: 29.12.2020).

2. Линник Ю. Засоби дистанщйного навчання: поняття та класифікащія. Наука $і$ молодь. Прикладна серія. Волинський національний університет імені Лесі Українки. Луцьк. URL: https://evnuir.vnu.edu.ua/ bitstream/123456789/14512/1/3415-9075-1-SM.pdf (дата звернення: 20.03.2021).

3. Романовський О. Дистанційна форма здобуття вищої освіти: аналіз, думки студентів щодо якості, переваг та недоліків. Інформаційні технології та засоби навчання. Харків, 2020. URL: http://repository.kpi.kharkov.ua/ bitstream/KhPI-Press/49166/1/ITZN_2020_79_5_Moroz_Dystantsiina_forma.pdf (дата звернення: 19.02.2021).

4. Квасник О., Ковтун Х. Особливості комунікативної компетентності учасників навчального процесу під час дистанційного навчання. Збірник наукових праць SCIENTIA. 2021. URL: http://surl.li/kscr (дата звернення: 21.03.2021).

5. Підлужна Г. Житомирський державний університет імені Івана Франка. URL: http://eprints.zu.edu.ua/2557 3/1/\%D0\%9F\%D1\%96\%D0\%B4\%D0\%BB\%D1\%83\%D0\%B6\%D0\%BD\%D0\%B0.pdf (дата звернення: 19.03.2021).

6. Борецька Г. Методика формування іншомовної компетентності у читанні. Київський національний лінгвістичний університет. Інозелні мови. 2012. Вип. 3(71). URL: https://cutt.ly/Bxfoq5S (дата звернення: 02.03.2021).

7. Партитура художнього тексту. Уманський державний педагогічний університет. URL: https://cutt.ly/OxfolzZ (дата звернення: 22.12.2020).

8. Забіла Н. Кіт і півник (віршована казка). Дитячий сайт «Казкар». URL: http://kazkar.at.ua/publ/avtorska kazka/natalja_zabila/kit_i_pivnik_virshovana_kazka/30-1-0-124 (дата звернення: 22.12.2020).

\section{References:}

1. Levochkin S. On the National Strategy for Education Development in Ukraine until 2021. URL: http://ru.osvita.ua/ legislation/other/36322/ (accessed 29 December 2020).

2. Linnyk Y. Distance learning tools: concepts and classification. Science and youth. Applied series. Lesya Ukrainka Volyn National University. Lutsk. URL: https://evnuir.vnu.edu.ua/bitstream/123456789/14512/1/3415-9075-1-SM.pdf (accessed 20 March 2021).

3. Romanovsky O. (2020) Distance form of higher education: analysis, students' opinions on quality, advantages and disadvantages. Information technologies and teaching aids. Kharkiv. URL: http://repository.kpi.kharkov. ua/bitstream/KhPI-Press/49166/1/ITZN_2020_79_5_Moroz_Dystantsiina_forma.pdf (accessed 19 February 2021).

4. Kvasnyk O., Kovtun H. (2021) Features of communicative competence of participants in the learning process during distance learning. Collection of scientific works SCIENTIA. URL: http://surl.li/kscr (accessed 21 March 2021).

5. Pidluzhna G. Zhytomyr State University named after Ivan Franko. URL: http://eprints.zu.edu.ua/25573/1/\%D0\% 9F\%D1\%96\%D0\%B4\%D0\%BB\%D1\%83\%D0\%B6\%D0\%BD\%D0\%B0.pdf (accessed 19 March 2021).

6. Boretska G. (2012) Methods of forming foreign language competence in reading. Kyiv National Linguistic University. Foreign languages, vol. 3(71). URL: https://cutt.ly/Bxfoq5S (accessed 02 March 2021).

7. Uman State Pedagogical University. Score of the artistic text. URL: https://cutt.ly/OxfolzZ (accessed 22 December 2020).

8. Killed N. Cat and rooster (poetic tale). Children's site "Kazkar". URL: http://kazkar.at.ua/publ/avtorska_kazka/ natalja_zabila/kit_i_pivnik_virshovana_kazka/30-1-0-124 (accessed 22 December 2020). 